- Faktor - faktor Yang Mempengaruhi Kinerja Transaksi Berjalan Indonesia

- Indonesian Japan Economic Relations : (Investment and Trade)

- Analisis Kinerja Industri TPT Indonesia

- Kajian Atas Perlakuan Akuntansi Terhadap Skema Perdagangan Emisi (Emission Trading Scheme) Pelajaran Dari Uni Eropa dan Australia

- Kajian Kebijakan PPN Atas Bahan Bakar Minyak Untuk Kapal Tujuan Internasional (Study on Value Added Tax Policy on International Bunker Fuen

\begin{tabular}{|c|c|c|c|c|c|}
\hline Kaj. Eko. \& Keu. & Vol. 14 & No. 4 & Jakarta 2010 & $\begin{array}{c}\text { ISSN 1410- } \\
3249\end{array}$ & $\begin{array}{c}\text { Terakreditasi B } \\
\text { (No. Akreditasi : } \\
\text { 306/AU2/P2MBI/08/2010) }\end{array}$ \\
\hline
\end{tabular}




\section{K A J I A N}

EKONOMI

KEUANGAN

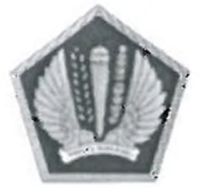

Pusat Kebijakan Ekonomi Makro

Badan Kebijakan Fiskal

Kementerian Keuangan RI

Faktor-faktor Yang Mempengaruhi Kinerja Transaksi

Berjalan Indonesia

(5)

Indonesia Japan Economic Relations: (Investment and Trade)

2

Analisis Kinerja Industri TPT Indonesia

证

Kajian Atas Perlakuan Akuntansi Terhadap Skema

Perdagangan Emisi (Emission Trading Scheme)

Pelajaran dari Uni Eropa dan Australia

Kajian Kebijakan PPN Atas Bahan Bakar Minyak. Untuk Kapal

Tujuan Internasional (Study On Value Added Tax Policy On Internasional Bunker Fuel)

\begin{tabular}{|l|l|l|l|l|}
\hline Kaj. Eko. \& Keu. & Vol. 14 & No.4 & Jakarta 2010 & ISSN 1410-3249 \\
\hline
\end{tabular} 


\section{KATA SAMBUTAN}

Kami panjatkan rasa syukur kepada Tuhan Yang Maha Esa atas terbitnya Kajian Ekonomi dan Keuangan edisi ini ke hadapan pembaca sekalian. Pada edisi ini, kami menyajikan berbagai topik yang berkaitan dengan analisis dan dampak kebijakan publik di bidang ekonomi dan keuangan negara.

Kajian pada volume kali ini diisi oleh berbagai topik tulisan yaitu FaktorFaktor yang Mempengaruhi Kinerja Transaksi Berjalan Indonesia; Indonesia Japan Economic Relations:(Investment and Trade); Analisis Kinerja Industri TPT Indonesia; Kajian Atas Perlakuan Akuntansi Terhadap Skema Perdagangan Emisi (Emission Trading Scheme) Pelajaran Dari Uni Eropa Dan Australia; dan Kajian Kebijakan PPN Atas Bahan Bakar Minyak Untuk Kapal Tujuan Internasional (Study On Value Added Tax Policy On Internasional Bunker Fuel). Adapun para penulis yang berkontribusi pada penerbitan kali ini yaitu Rudi Handoko, Suparman Zen Kemu, Ragimun, Mahpud Sujai, dan I Nyoman Widia.

Demikianlah kata pengantar yang dapat kami sampaikan. Ibarat peribahasa tiada gading yang tak retak, maka kami menyadari kajian ini tentunya masih terdapat kekurangan baik yang disengaja maupun yang tidak kami sengaja. Oleh karena itu, kami mengharapkan masukan dari para pembaca guna perbaikan di masa yang akan datang. Selanjutnya, kami berharap jurnal ini dapat memberikan manfaat kepada para pembaca sekalian. Selamat membaca!

Jakarta, 2010

Dewan Redaksi 



\section{DAFTAR ISI}

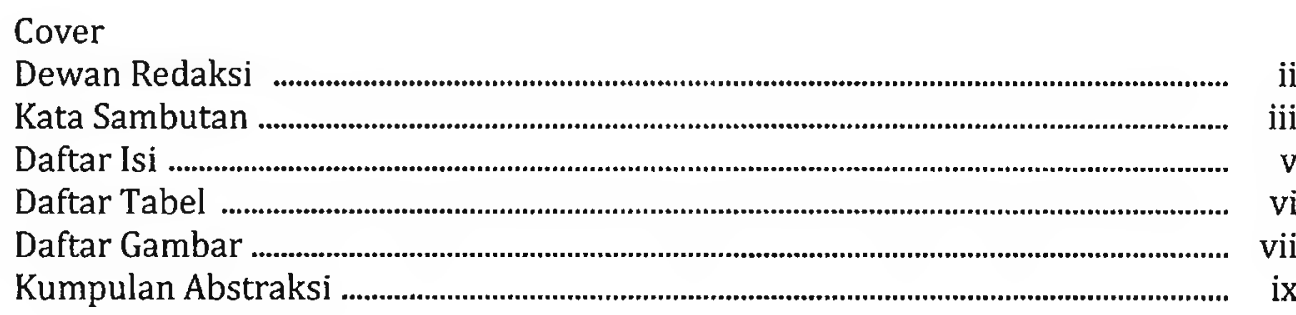

FAKTOR-FAKTOR YANG MEMPENGARUHI KINERJA TRANSAKSI

BERJALAN INDONESIA

Oleh: Rudi Handoko

INDONESIA JAPAN ECONOMIC RELATIONS:

(INVESTMENT AND TRADE)

Oleh: Suparman Zen Kemu

\section{ANALISIS KINERJA INDUSTRI TPT INDONESIA}

Oleh: Ragimun

\section{KAJIAN ATAS PERLAKUAN AKUNTANSI TERHADAP SKEMA \\ PERDAGANGAN EMISI (EMISSION TRADING SCHEME) \\ PELAJARAN DARI UNI EROPA DAN AUSTRALIA}

Oleh: Mahpud Sujai

KAJIAN KEBIJAKAN PPN ATAS BAHAN BAKAR MINYAK

UNTUK KAPAL TUJUAN INTERNASIONAL (STUDY ON VALUE ADDED

TAX POLICY ON INTERNATIONAL BUNKER FUEL)

Oleh: I Nyoman Widia 


\section{DAFTAR TABEL}

INDONESIA JAPAN ECONOMIC RELATIONS: (INVESTMENT AND TRADE)

Tabel 2.1. Japanese Foreign Investment Destination

\section{ANALISIS KINERJA INDUSTRI TPT INDONESIA}

Tabel 3.1. Profil Industri TPT Indonesia tahun 2004-2008...................................... 50

Tabel 3.2. Program Peningkatan Kinerja Industri TPT ............................................ 53

Tabel 3.3. Faktor-Faktor Yang Mempengaruhi Daya Saing Industri TPT Indonesia dengan China 57

Tabel 3.4. Struktur Biaya Tekstil dan Produk Tekstil (\%) 58

KAJIAN ATAS PERLAKUAN AKUNTANSI TERHADAP SKEMA

PERDAGANGAN EMISI (EMISSION TRADING SCHEME)

PELAJARAN DARI UNI EROPA DAN AUSTRALIA

Tabel 1.1. GHG Emissions Summary(MtCO2e)

\section{KAJIAN KEBIJAKAN PPN ATAS BAHAN BAKAR MINYAK} UNTUK KAPAL TUJUAN INTERNASIONAL (STUDY ON VALUE ADDED TAX POLICY ON INTERNASIONAL BUNKER FUEL)

Tabel 1.1. Penerimaan Perpajakan 2005 - 2010 (Triliun Rupiah) 78

Tabel 3.1. Perbandingan Penjualan BBM Indonesia dan Singapura (kilo liter) 


\section{DAFTAR GAMBAR}

\section{FAKTOR-FAKTOR YANG MEMPENGARUHI KINERJA TRANSAKSI BERJALAN INDONESIA}

Gambar 3.1. Neraca Transaksi Berjalan dan Neraca Perdagangan 1960 - 1979

(US\$ juta)

Gambar 3.2. Ekspor Minyak dan Bukan Minyak 1960 - 1979

(US\$ juta)

Gambar 3.3. Neraca Transaksi Berjalan dan Neraca Perdagangan 1980 - 1991 (US\$ juta)

Gambar 3.4. Ekspor Minyak dan Gas 1980 - 1991 (US\$ juta) 10

Gambar 3.5. Komponen Neraca Transaksi Berjalan 1992 - 2003 (US\$ juta)

Gambar 3.6. Neraca Transaksi Berjalan dan Neraca Perdagangan $1992-2003$ (US\$ juta)

Gambar 3.7. Neraca Transaksi Berjalan dan Neraca Perdagangan Q1 2004 - Q2 2010 (US\$ juta)

Gambar 3.8. Neraca Transaksi Berjalan dan Neraca Perdagangan Non Migas Q1 2004 - Q2 2010 (US\$ juta). 14

Gambar 3.9. Neraca Transaksi Berjalan dan Neraca Perdagangan Migas Q1 2004 - Q2 2010 (US\$ juta)

Gambar 3.10. Neraca Transaksi Berjalan dan Neraca Perdagangan Minyak Q1 2004 - Q2 2010 (US\$ juta)

Gambar 3.11. Neraca Transaksi Berjalan dan Neraca Perdagangan Gas Q1 $2004-$ Q2 2010 (US\$ juta)

Gambar 3.12. Neraca Transaksi Berjalan dan Jasa-jasa Q1 2004 - Q2 2010 (US\$ juta) 17

Gambar 3.13. Neraca Transaksi Berjalan dan Pendapatan Q1 2004 - Q2 2010 (US\$ juta) 18

Gambar 3.14. Neraca Transaksi Berjalan dan Transfer Q1 2004 - Q2 2010 (US\$ juta) 18

Gambar 3.15. Hubungan Transaksi Berjalan dan Pertumbuhan Ekonomi Domestik

Gambar 3.16. Hubungan Transaksi Berjalan dan Pertumbuhan Ekonomi Dunia

Gambar 3.17. Transaksi Berjalan dan Harga Komoditas. 21

Gambar 3.17. Transaksi Berjalan dan Nilai Tukar 22 
INDONESIA JAPAN ECONOMIC RELATIONS: (INVESTMENT AND TRADE)

Graph 2.1. Indonesian non-oil exports by destination country (US\$ billion)

Graph 2.2. Indonesia Japanese import and export (Billion Yen).

\section{ANALISIS KINERJA INDUSTRI TPT INDONESIA}

Grafik 3.1. Jumlah Perusahaan dan Jumlah Share Industri TPT

Tahun 2008-2009 


\begin{tabular}{|c|}
\hline $\begin{array}{l}\text { MAJALAH KAJIAN EKONOMI DAN KEUANGAN } \\
\text { ISSN 1410-3249 } \\
\text { KEK Terakreditasi B } \\
\text { (No. Akreditasi : 306/AU2/P2MBI/08/2010) } \\
\text { Volume 14 Nomor 4 Tahun } 2010\end{array}$ \\
\hline $\begin{array}{c}\text { Keywords used are free terms. Abstracts can be reproduced without } \\
\text { permission or charge. }\end{array}$ \\
\hline ABSTRAKSI \\
\hline $\begin{array}{l}\text { Handoko, Rudi, et. al. (Badan Kebijakan Fiskal, Kementerian Keuangan) } \\
\text { Faktor-Faktor Yang Mempengaruhi Kinerja Transaksi Berjalan Indonesia } \\
\text { Kajian Ekonomi dan Keuangan Volume } 14 \text { Nomor } 4 \text { Tahun 2010, halaman } \\
\text { 1-24 }\end{array}$ \\
\hline $\begin{array}{l}\text { This paper attempt to describe factors affecting the performance of current } \\
\text { account in Indonesia. Current account performance is showed by surplus or } \\
\text { deficit position. Analysis of the factors is conducted based on periodization of } \\
\text { current account performance. Other analysis was carried out by using scatter } \\
\text { graph to show the relationship between two variables in question. The results } \\
\text { show that some factors affecting current account performance are global } \\
\text { economic growth, Indonesian major trading partners growth, domestic } \\
\text { economic growth, international commodities prices, exchange rate } \\
\text { management, economic policy, and financial crisis. } \\
\text { Keyword: current account, balance of payment, externalsector, trade } \\
\text { balance }\end{array}$ \\
\hline $\begin{array}{l}\text { Zen Kemu, Suparman, et. al. (Badan Kebijakan Fiskal, Kementerian } \\
\text { Keuangan) } \\
\text { Indonesia Japan Economic Relations: (Investment and Trade) } \\
\text { Kajian Ekonomi dan Keuangan Volume } 14 \text { Nomor } 4 \text { Tahun 2010, halaman } \\
25-40\end{array}$ \\
\hline $\begin{array}{l}\text { Pra krisis ekonomi 1998, Indonesia merupakan Negara urutan ketiga dalam } \\
\text { tujuan investasi langsung Jepang (FDI), dibawah China dan Amerika Serikat. } \\
\text { Namun, paska krisis ekonomi } 1998 \text { tersebut, posisi Indonesia turun ke } \\
\text { ranking kedelapan dan telah dilewati oleh India, Thailand, Vietnam, Rusia, } \\
\text { dan Brazil. Beberapa faktor yang menyebabkan terjadinya hal ini adalah: } \\
\text { kondisi infrastruktur yang buruk di dalam negeri terutama masalah } \\
\text { perlistrikan, kurangnya kepastian hukum, adanya pajak berganda, fluktuasi }\end{array}$ \\
\hline
\end{tabular}




\begin{tabular}{|c|}
\hline $\begin{array}{c}\text { MAJALAH KAJIAN EKONOMI DAN KEUANGAN } \\
\text { ISSN 1410-3249 } \\
\text { KEK Terakreditasi B } \\
\text { (No. Akreditasi : 306/AU2/P2MBI/08/2010) } \\
\text { Volume 14 Nomor } 4 \text { Tahun } 2010\end{array}$ \\
\hline $\begin{array}{l}\text { Keywords used are free terms. Abstracts can be reproduced without } \\
\text { permission or charge. }\end{array}$ \\
\hline ABSTRAKSI \\
\hline $\begin{array}{l}\text { nilai tukar rupiah yang terlampau tajam, dan lemahnya hubungan antar } \\
\text { industrI (linkage). Dalam perdagangan luar negeri Jepang merupakan } \\
\text { partner dagang terbesar Indonesia. Pada tahun 2007, total perdagangan } \\
\text { Indonesia Jepang mencapai nilai USD 23,6, merupakan yang terbesar di } \\
\text { ASEAN dibandingkan perdagangan Negara anggota ASEAN lainnya } \\
\text { terhadap Jepang. Namun jenis ekspor Indonesia ke Jepang di dominasi oleh } \\
\text { komoditi dasar seperti minyak bumi, gas, bahan tambang, dan produk kayu. } \\
\text { Sementara ekspor Negara anggota ASEAN yang lain ke Jepang seperti } \\
\text { Singapura, Thailand dan Malaysia didominasi produk manufaktur berupa } \\
\text { komponen yang mempunyai nilai tambah lebih tinggi. Gejala lainnya adalah } \\
\text { bahwa ada tendensi peningkatan nilai perdagangan Indonesia dengan dua } \\
\text { Negara Asia Timur yaitu China dan Korea. Hal ini positif bagi Indonesia } \\
\text { namun kurang baik bagi kelanjutan hubungan ekonomi Indonesia Jepang. } \\
\text { Berbagai masalah ini perlu dibicarakan secara lebih serius oleh kedua } \\
\text { Negara agar nilai perdagangan dan investasi Indonesia Jepang dapat lebih } \\
\text { meningkat lagi. }\end{array}$ \\
\hline $\begin{array}{l}\text { Ragimun, et. al. (Badan Kebijakan Fiskal, Kementerian Keuangan) } \\
\text { Analisis Kinerja Industri TPT Indonesia } \\
\text { Kajian Ekonomi dan Keuangan Volume } 14 \text { Nomor } 4 \text { Tahun 2010, halaman } \\
\text { 41-62 }\end{array}$ \\
\hline $\begin{array}{l}\text { Textile industry can be categorized the oldest industry in Indonesia. This is a } \\
\text { significant industry, which provides not only on economic contribution but } \\
\text { also on absorbing employment for the total } 15 \% \text { of all manufacture sectors. } \\
\text { At the present, textile industry is facing some structural problems, such as the } \\
\text { high cost of energy, insufficient of infrastructure, the low technology and } \\
\text { well-worn of the machines, and also the overflowing of China's textiles into } \\
\text { Indonesia markets. Those are causing high cost of production and further } \\
\text { impeding competitiveness of domestic textile in the world market. } \\
\text { On the early stage, the textile industry development was boosted by the } \\
\text { Foreign Investment Law (1967) and the Domestic Investment Law (1968). In } \\
\text { addition, the export quota system grows up steadily during the period of } \\
1984 \text { to } 2000, \text { which reach to } 18,5 \% \text { per year. For the last } 5 \text { years, however, } \\
\text { the export shows a fluctuation. For } 2000 \text {, the number reaches US\$8.3 billion, } \\
\text { and in } 2009 \text { goes to US } \$ 9.26 \text { billion or just a tiny increase of } 3.41 \% \text { per year. }\end{array}$ \\
\hline
\end{tabular}




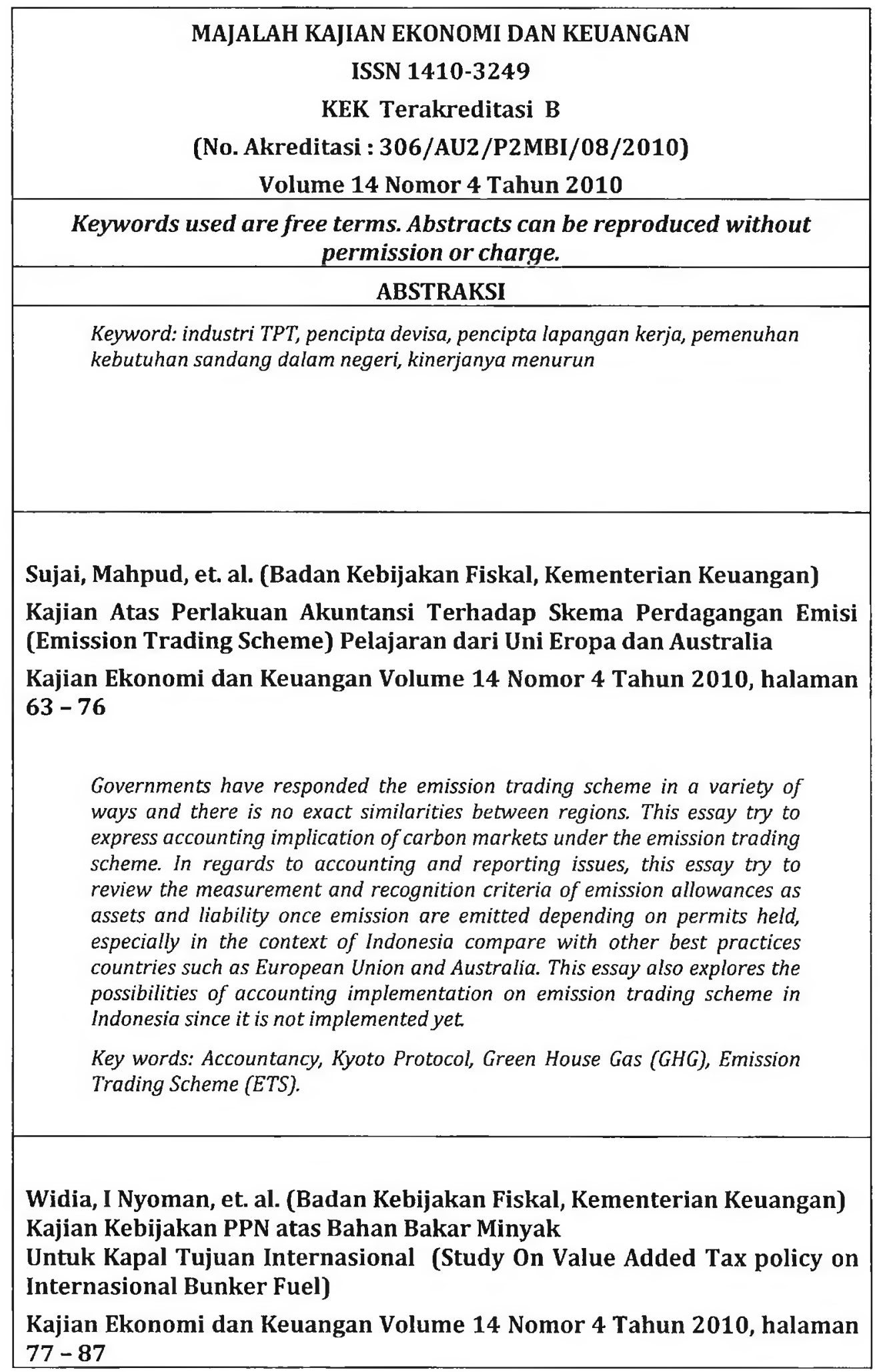


MAJALAH KAJIAN EKONOMI DAN KEUANGAN

ISSN 1410-3249

KEK Terakreditasi B

(No. Akreditasi : 306/AU2/P2MBI/08/2010)

Volume 14 Nomor 4 Tahun 2010

Keywords used are free terms. Abstracts can be reproduced without permission or charge.

ABSTRAKSI

This study focus on value added tax policy on international bunker fuel. Current regulation in Indonesia describes that government has imposed value added tax $10 \%$ on bunker fuel. Qualitative Approach was used in this study. As a result, imposing value added tax on bunker fuel against the international best practice. According to Value Added Tax Law, Government of Indonesia may give an incentive on bunker fuel.

Keywords: value added tax, international bunker fuel, incentive 


\title{
ANALISIS KINERJA INDUSTRI TPT INDONESIA
}

\author{
Oleh:
}

Ragimun $^{1}$

\begin{abstract}
Textile industry can be categorized the oldest industry in Indonesia. This is a significant industry, which provides not only on economic contribution but also on absorbing employment for the total $15 \%$ of all manufacture sectors.

At the present, textile industry is facing some structural problems, such as the high cost of energy, insufficient of infrastructure, the low technology and wellworn of the machines, and also the overflowing of China's textiles into Indonesia markets. Those are causing high cost of production and further impeding competitiveness of domestic textile in the world market.

On the early stage, the textile industry development was boosted by the Foreign Investment Law (1967) and the Domestic Investment Law (1968). In addition, the export quota system grows up steadily during the period of 1984 to 2000, which reach to $18,5 \%$ per year. For the last 5 years, however, the export shows a fluctuation. For 2000, the number reaches US\$ 8.3 billion, and in 2009 goes to US\$ 9.26 billion or just a tiny increase of $3.41 \%$ per year.

Keyword: industri TPT, pencipta devisa, pencipta lapangan kerja, pemenuhan kebutuhan sandang dalam negeri, kinerjanya menurun
\end{abstract}

\section{PENDAHULUAN}

\subsection{Latar Belakang}

Industri TPT (Tekstil dan Produk Tekstil) Indonesia merupakan industri strategis dan mempunyai prospek pasar yang cukup menjanjikan. Tiga peran utamanya adalah penciptaan devisa negara, penciptaan lapangan kerja dan pemenuhan kebutuhan sandang dalam negeri. Selain mampu menyerap tenaga kerja sebesar $15 \%$ atau sebanyak 1.841 .520 orang dari total tenaga kerja di sektor manufaktur, juga memberikan kontribusi terhadap surplus perdagangan sebesar 24,33\% pada tahun 2007, bahkan pada saat krisis global di tahun 2008 ekspor industri Tekstil dan Produk Tekstil (TPT) masih mampu meraih surplus 5 (lima) milyar dollar Amerika. ${ }^{2}$

I Peneliti Pusat Kebijakan Ekonomi Makro Badan Kebijakan Fiskal

2 Ansari Bukhari, 2010 dalam bahan seminarnya berjudul "Dukungan Pemerintah Dalam Peningkatan Daya Saing Industri TPT Indonesia Menghadapi Integrasi Tekstil Asean" pada seminar nasional di Arena PRJ, 22 April 2010. Data dari Biro Pusat Statistik per Februari 2010 menyebutkan bahwa total tenaga kerja menurut lapangan pekerjaan utama untuk sektor industri adalah sebesar 13,05 juta orang. 
Pemerintah menyadari bahwa dalam era globalisasi daya saing TPT merupakan hal penting, untuk itu berbagai program telah disiapkan untuk memberi arah bagi pengembangan industri nasional sebagaimana termuat dalam Kebijakan Industri Nasional (KIN), Rencana Strategis (Renstra), Rencana Pembangunan Jangka Menengah (RPJM) maupun Rencana Pembangunan Jangka Panjang (RPJP).

Upaya yang sudah dilakukan pemerintah dalam rangka peningkatan daya saing industri TPT antara lain : (1) Pemerintah melakukan program restrukturisasi permesinan melalui modernisasi permesinan ITPT (Industri Tekstil dan Produk Tekstil) yang bertujuan untuk meningkatkan efisiensi, meningkatkan produktivitas dan kualitas produknya serta kualitas lingkungan; (2) Pemerintah memberikan bantuan dengan skema (scheme) potongan harga sebesar $10 \%$ atas mesin-mesin yang dibeli, atau keringanan suku bunga kredit dimana industri hanya membayar 7\% bunga kreditnya; (3) Selama tahun 2006 sampai dengan 2009, Pemerintah telah melaksanakan Program Audit Energi dan Bimbingan Konservasi Energi termasuk pengembangan teknologi produksi ITPT melalui kerjasama dengan negara berteknologi maju serta memfasilitasi industri TPT untuk memperoleh fasilitas bea masuk ditanggung pemerintah bagi importasi bahan baku/bahan penolong.

Peluang dan tantangan ke depan yang masih harus dilakukan pemerintah antara lain pemberian beberapa fasilitas baik perbankan, fiskal maupun non fiskal serta pengembangan investasi pertekstilan, pengembangan dan penerapan nanoteknologi khususnya dibidang dyeing dan finishing serta pengembangan penelitian yang bersinergi dengan kebutuhan ITPT termasuk lembaga pendidikan pertekstilan di Indonesia. ${ }^{3}$

\subsection{Perumusan Masalah}

Akibat berbagai pengaruh ekonomi yang bersifat eksternal maupun internal, kinerja ITPT Indonesia sekarang ini mengalami perlambatan. Faktor eksternal antara lain pengaruh krisis ekonomi global tahun 2008 termasuk banyaknya produk ITPT yang masuk ke pasaran Indonesia terutama dari China baik legal maupun illegal. Demikian juga masalah-masalah internal seperti biaya energi yang cukup besar, infrastruktur di pelabuhan yang tidak kondusif serta mesin-mesin yang sudah relatif tua. Permasalahan-permasalahan inilah yang kemudian mengganggu kinerja dan daya saing ITPT di Indonesia akhir-akhir ini.

3 Ansari Bukhari, bahan seminarnya berjudul "Dukungan Pemerintah Dalam Peningkatan Daya Saing Industri TPT Indonesia Menghadapi Integrasi Tekstil Asean” pada seminar nasional di Arena PRJ, 22 April 2010. 


\subsection{Tujuan Penelitian}

Penelitian ini bertujuan menganalisis mengenai ITPT Indonesia yang menggambarkan kinerja dan daya saing ITPT di Indonesia. Disamping itu dapat diketahui faktor-faktor yang menyebabkan penurunan kinerja ITPT Indonesia tersebut, yang disinyalir mengalami perlambatan akhir-kahir ini. Demikian juga dapat diketahui langkah-langkah kebijakan yang dapat dilakukan pemerintah.

\subsection{Metodologi Penelitian}

Untuk menganalisis kinerja ITPT Indonesia digunakan metode kualitatif dengan pendekatan eksploratif deskriptif. Pendekatan eksploratif, menurut Philip Kotler dan Kevin Lane Keller dalam bukunya Metodologi Penelitian:Aplikasi Dalam Pemasaran, 2006, halaman 122, adalah penelitian yang bertujuan menghimpun informasi awal yang akan membantu upaya menetapkan masalah dan merumuskan hipotesis. Sedangkan pendekatan deskriptif adalah penelitian yang tujuannya memaparkan (mendeskripsikan) sesuatu. Jadi pendekatan ini bertujuan untuk mendalami dan menggambarkan perkembangan, kinerja dan daya saing ITPT Indonesia. Bahan-bahan, data sekunder dan informasi didapat dari penggalian dan informasi yang berasal dari berbagai sumber, bahan seminar serta didukung pula dengan kajian pustaka.

\section{TINJAUAN PUSTAKA}

\subsection{Industri TPT di Indonesia}

Keberadaan industri TPT di Indonesia tidak dapat dipastikan sejak kapan berdiri, namun kemampuan masyarakat Indonesia dalam hal menenun dan merajut pakaian sudah dimulai sejak berdirinya kerajaan-kerajaan Hindu di Indonesia dalam bentuk kerajinan, yaitu tenun-menenun dan membatik yang hanya berkembang di sekitar lingkungan istana dan hanya untuk kepentingan seni dan budaya serta dikonsumsi sendiri.

Sedangkan perkembangan pertekstilan Indonesia dimulai dari industri rumahan (home industry) tahun 1929 dimulai dari sub-sektor pertenunan (weaving) dan perajutan (knitting) dengan menggunakan alat Textile Inrichting Bandung (TIB) Gethouw atau yang dikenal dengan nama Alat Tenun Bukan Mesin (ATBM) yang diciptakan oleh Daalennoord pada tahun 1926 dengan produknya berupa tekstil tradisional seperti sarung, kain panjang, lurik, stagen (sabuk), dan selendang. Penggunaan ATBM mulai tergeser oleh Alat Tenun Mesin (ATM) yang pertama kali digunakan pada tahun 1939 di Majalaya-Jawa Barat. Sejak itu industri TPT Indonesia mulai memasuki era teknologi dengan menggunakan ATM. 
Era tahun 1960-an, sesuai dengan iklim ekonomi terpimpin, pemerintah Indonesia membentuk Organisasi Perusahaan Sejenis (OPS) yang antara lain seperti OPS Tenun Mesin, OPS Tenun Tangan, OPS Perajutan, OPS Batik, dan lainlain yang dikoordinir oleh Gabungan Perusahaan Sejenis (GPS) Tekstil dimana pengurus GPS Tekstil tersebut ditetapkan dan diangkat oleh Menteri Perindustrian Rakyat dengan perkembangannya sebagai berikut:

1. Pertengahan tahun 1965 -an, OPS dan GPS dilebur menjadi satu dengan nama OPS Tekstil dengan beberapa bagian menurut jenisnya atau sub-sektornya, yaitu pemintalan (spinning), pertenunan (weaving), perajutan (knitting), dan penyempurnaan (finishing).

2. Menjelang tahun 1970, berdirilah berbagai organisasi seperti Perteksi, Printer's Club (kemudian menjadi Textile Club), perusahaan milik pemerintah (Industri Sandang, Pinda Sandang Jabar, Pinda Sandang Jateng, Pinda Sandang Jatim), dan Koperasi (GKBI, Inkopteksi).

3. Tanggal 17 Juni 1974, organisasi-organisasi tersebut melaksanakan Kongres yang hasilnya menyepakati mendirikan Asosiasi Pertekstilan Indonesia (API) dan sekaligus menjadi anggota API.

Perkembangan industri TPT di Indonesia diawali pada tahun 1970-an dengan masuknya investasi dari Jepang di sub-sektor industri hulu (spinning dan man-made fiber making). Adapun perkembangannya dapat digambarkan sebagai berikut:

1. Era tahun 1970 - 1985, industri TPT Indonesia tumbuh lamban serta terbatas dan hanya mampu memenuhi pasar domestik (substitusi impor) dengan segmen pasar menengah-rendah.

2. Tahun 1986, industri TPT Indonesia mulai tumbuh pesat dengan faktor utamannya adalah: (1) iklim usaha kondusif, seperti regulasi pemerintah yang efektif yang difokuskan pada ekspor non-migas, dan (2) industrinya mampu memenuhi standard kualitas tinggi untuk memasuki pasar ekspor di segmen pasar atas.

3. Periode 1986-1997 kinerja ekspor industri TPT Indonesia terus meningkat dan membuktikan sebagai industri yang strategis dan sekaligus sebagai andalan penghasil devisa negara sektor non-migas. Pada periode ini pakaian jadi sebagai komoditi primadona.

4. Periode 1998-2002 merupakan masa paling sulit karena krisis ekonomi di Indonesia. Kinerja ekspor tekstil nasional sangat fluktuatif. Pada periode ini dapat dikatakan sebagai periode survival.

5. Periode 2003 - 2006 merupakan outstanding rehabilitation, normalization, dan expansion, artinya periode ini memerlukan upaya revitalisasi yang disebabkan beberapa kendala, antara lain sulitnya sumber-sumber pembiayaan dan iklim usaha yang tidak kondusif. 
Kinerja ekspor industri TPT Indonesia sempat mengalami penurunan yang cukup signifikan pada 2003. Namun demikian, sejak 2004 kinerjanya terus mengalami kenaikan baik dari sisi volume maupun nilai ekspor. Bahkan volume maupun nilai ekspor yang dicapai pada 2006 telah melampaui volume dan nilai ekspor pada tahun 2000. Lebih dari separuh nilai ekspor dikontribusi oleh industri garmen yang mencapai 55,7 persen (USD 5,27 juta), diikuti oleh industri pemintalan sebesar 18,9 persen, dan industri pertenunan.

Volume penjualan (konsumsi) dalam negeri juga mengalami kenaikan yang cukup signifikan, yakni dari 836 ribu ton pada 2005 menjadi 1,050 ribu ton pada 2006. Kenaikan konsumsi yang tinggi ini diperkirakan lebih dari separuhnya dipasok dari tekstil impor ilegal. Diperkirakan jumlah tekstil impor ilegal di pasar domestik mencapai $58 \%$ pada 2005 , dan $50 \%$ pada 2006, jauh diatas pasokan industri TPT domestik yang hanya sebesar $36 \%$ pada 2005 dan $45 \%$ pada 2006. Meningkatnya impor ilegal tersebut disebabkan antara lain harga, disain dan kualitas yang sangat bersaing.

Perkembangan investasi untuk industri TPT cenderung stagnan sepanjang 2001-2005. Namun pada 2006 terjadi sedikit kenaikan sebesar Rp 3,34 triliun. Peningkatan investasi ini terutama terjadi dalam PMA (Penanaman Modal Asing). Pada 2006, PMA mencapai US\$ 418 juta atau meningkat 490\% dibanding 2005, sedangkan PMDN (Penanaman Modal Dalam Negeri) sebesar Rp 80 miliar atau turun $2100 \%$ dibanding 2005. Selama awal tahun 2006 terdapat 40 perusahaan asal Korea yang menanamkan modalnya di sektor TPT dengan nilai investasi US\$ 375 juta.

6. Periode 2007-sekarang merupakan era dimulainya restrukturisasi permesinan industri TPT di Indonesia. Antara penggantian mesin-mesin yang lebih efisien demikian juga penambahan investasi asing. Tahun 2007, penambahan investasi asing masih terus berlangsung. Saat ini ada 4 negara yang mendominasi industri TPT di Indonesia yakni India (PT Indorama), Jepang (PT Summitmas Group), Korea Selatan (Korean Garmen Group), dan Taiwan (Taiwan Garmen Group).

Industri TPT secara teknis dan struktur terbagi dalam tiga sektor, yaitu :

1. Sektor industri hulu (upstream), adalah industri yang banyak memproduksi serat/fiber (natural fiber, man-made fiber atau synthetic) dan proses pemintalan (spinning) menjadi produk benang (unblended, blended yarn). Industrinya bersifat padat modal, full automatic, berskala besar, jumlah tenaga kerjanya relatif kecil.

2. Sektor industri menengah (midstream), meliputi proses penganyaman (interlacing) benang menjadi kain mentah lembaran (grey fabric) melalui proses pertenunan (weaving) dan rajut (knitting) yang kemudian diolah 
lebih lanjut melalui proses pengolahan pencelupan (dyeing), penyempurnaan (finishing) dan pencapan (printing) menjadi kain-jadi. Sifat dari industri ini adalah semi padat modal, teknologi modern dan mengikuti perkembangan, serta jumlah tenaga kerjanya lebih besar.

3. Sektor industri hilir (downstream), adalah industri manufaktur pakaian jadi (garment) termasuk proses cutting, sewing, washing dan finishing yang menghasilkan ready-made garment. Sektor ini adalah yang paling banyak menyerap tenaga kerja sehingga sifat industrinya adalah padat karya.

\subsection{Kontribusi Industri TPT pada Pertumbuhan Ekonomi dan Penyerapan Tenaga Kerja}

Tingginya pasokan tenaga kerja di satu sisi dan lambannya penyerapan tenaga kerja di lain sisi merupakan salah satu masalah besar yang dihadapi hampir semua perekonomian negara sedang berkembang (Todaro, 1997). Untuk kasus Indonesia, kecenderungan tersebut semakin tampak jelas. Selama periode 19952000, misalnya, angka pertumbuhan kesempatan kerja masih tertinggal 4 sampai 4,5 persen dari pertumbuhan angkatan kerja. Konsekuensinya, angka pangangguran terbuka (open unemployment) masih tetap tinggi. Diperkirakan angka total pengangguran masih tinggi. Tercatat pengangguran tahun 2008 dan 2009 sebesar 9,39 juta orang dan 8,96 juta orang. Dan beban pengangguran ini akan semakin kompleks, karena kenyataannya bahwa kesempatan kerja tidak selalu dapat terjelma menjadi penyerapan tenaga kerja dan tenaga kerja yang terserap bisa mempunyai lebih dari satu pekerjaan (Pasay dan Taufik, 1990). Persoalan penciptaan kesempatan kerja di atas akan semakin bertambah berat lagi bila ditinjau sisi kualitas kesempatan kerja itu sendiri (Kuncoro, 1999). Bila penyerapan tenaga kerja yang produktif remuneratif dapat dipandang sebagai kesempatan kerja yang dikehendaki, maka perluasan kesempatan kerja yang berhasil diciptakan selama periode yang sama masih jauh dari harapan. Angka pertumbuhan kesempatan kerja yang berstatus informal masih lebih tinggi dari angka kesempatan kerja berstatus formal.

\subsection{Daya Saing Industri TPT}

Pemerintah menyadari bahwa dalam perdagangan internasional sekarang ini daya saing industri tekstil merupakan faktor penting. Untuk itu berbagai program telah disiapkan untuk memberi arah bagi pengembangan industri nasional sebagaimana termuat dalam Kebijakan Industri Nasional (KIN), Rencana Strategis (Renstra), Rencana Pembangunan Jangka Menengah (RPJM) maupun dalam Rencana Pembangunan Jangka Panjang (RPJP). 
Industri TPT di Indonesia mempunyai banyak kendala dan hambatan dalam peningkatan daya saing. Ada 10 masalah yang menjadi pemicu rendahnya daya saing industri tekstil di Indonesia. Masalah itu meliputi rendahnya teknologi, ketergantungan bahan baku impor, minimnya industri pendukung, rendahnya sumber daya manusia, keterbatasan modal kerja, pasokan listrik, agresifnya produk tekstil, lemahnya kinerja ekspor, persoalan transportasi, dan persoalan pajak. ${ }^{4}$

Beberapa hal terkait dengan masalah sumber daya manusia dalam rangka peningkatan daya saing pada di industri TPT nasional, antara lain bahwa:

1. Tenaga kerja merupakan salah satu faktor yang sangat mempengaruhi peningkatan daya saing produk TPT nasional di pasar global diantara faktorfaktor yang lainnya, seperti perbankan, energi, infrastruktur dan jarak/letak geografis negara Indonesia.

2. Masalah tenaga kerja yang dihadapi industri TPT nasional yang mengakibatkan industri ini sulit bersaing dengan industri TPT dari negaranegara lain adalah rendahnya produktivitas pekerja. Hasil penelitian tentang “Pemeringkatan Daya Tarik Investasi Kabupaten/Kota pada Tahun 2003" oleh Komite Pemantauan Pelaksanaan Otonomi Daerah (KPPOD) adalah 1) Dari 156 kabupaten, hanya 13 kabupaten yang produktivitas tenaga kerjanya sangat tinggi. Tiga kabupaten produktivitas tenaga kerjanya tinggi, dan 24 kabupaten produktivitas tenaga kerjanya sedang. Sisanya, yaitu sebanyak 116 kabupaten adalah tenaga kerja yang produktivitasnya rendah dan sangat rendah. 2) Dari 44 kota, hanya 7 kota yang produktivitas tenaga kerjanya sangat tinggi, 5 kota yang produktivitas tenaga kerjanya tinggi, 14 kota yang produktivitas tenaga kerjanya sedang. Sisanya, yaitu sebanyak 18 kota adalah tenaga kerja yang produktivitasnya rendah dan sangat rendah.

Masalah lainnya adalah kekurangan tenaga profesional, antara lain disektor industri weaving untuk bidang pemasaran dan di sektor industri garmen untuk tenaga di bidang merchandizing dan marketing. Sedangkan hasil penelitian tentang kualitas pekerja, khususnya dalam hal pendidikan dan pengetahuan, adalah sebagai berikut:

1) Hasil kajian kuisioner kualitas tenaga kerja KPPOD terhadap 5.140 pelaku usaha di 200 kabupaten/kota, yaitu (i) Untuk usaha yang mempekerjakan lebih besar dari 100 tenaga kerja, 30,9\% pelaku usaha menilai kualitas tenaga kerjanya kurang baik. (ii) Sementara untuk usaha yang mempekerjakan antara $20 \mathrm{~s} / \mathrm{d} 100$ tenaga kerja, sebanyak 20,7\% pelaku usaha menilai kualitasnya kurang baik. (iii) Untuk usaha yang

\footnotetext{
4 Sumber : www.koran- jakarta.com/berita-detail.php?id=38342
} 
mempekerjakan lebih kecil dari 20 tenaga kerja, sebanyak 20,4\% pelaku usaha menilai kualitas tenaga kerjanya kurang baik.

2) Data dari Business News, September 2002, menyatakan dari total 100 juta jiwa pada tahun 2001 diketahui, (i) Berpendidikan rendah, yaitu 38\% Sekolah Dasar (SD). (ii) Berpendidikan menengah (SLTP dan SMU) sekitar $35 \%$. (iii) Tidak pernah lulus dan tidak pernah sekolah sekitar $22 \%$. (iv) Pendidikan Tinggi dan Diploma hanya 5\%, dan ini juga lebih dari setengahnya bekerja sebagai pegawai pemerintah baik Pegawai Negeri Sipil atau Badan Usaha Milik Negara ). ${ }^{5}$

\subsection{Regulasi dan Kebijakan Pemerintah Mengenai Industri TPT di Indonesia}

Menurut catatan Departemen Perindustrian, dari seluruh mesin TPT yang ada $(8,38$ juta unit mesin pada 2006), sekitar 80 persen diantaranya telah berusia diatas 20 tahun. Ini menyebabkan produktivitas menurun hingga 50 persen. Di Industri pemintalan jumlah mesin yang berusia diatas 20 tahun mencapai 64 persen (5.025.287 mata pintal dari 7.803.241 mata pintal). Di industri pertenunan jumlahnya mencapai 82,1 persen (204.393 ribu alat tenun mesin dibanding 248.957 unit), perajutan $84 \%$, finishing $93 \%$ dan pakaian jadi atau garmen $78 \%$.

Untuk merestrukturisasi mesin-mesin yang sudah tua tersebut dibutuhkan biaya sekitar Rp 44,07 triliun. Jumlah yang cukup besar tersebut terdiri dari restrukturisasi mesin di industri pemintalan sebesar $\mathrm{Rp} 13,26$ triliun, industri serat $\mathrm{Rp} \mathrm{8,07} \mathrm{triliun,} \mathrm{industri} \mathrm{tenun,} \mathrm{rajut} \mathrm{dan} \mathrm{finishing} \mathrm{Rp} \mathrm{20,9} \mathrm{triliun,} \mathrm{dan} \mathrm{industri}$ garmen $\mathrm{Rp} 1,84$ triliun.

Pemerintah senantiasa membantu industri TPT untuk merestrukturisasi mesin-mesinnya. Selama 2007, pemerintah telah menyalurkan dana sebesar Rp 255 miliar untuk membantu peningkatan teknologi atau restrukturisasi mesin industri TPT. Kucuran dana tersebut rencananya akan dilakukan lagi pada 2008 sebesar Rp 400 miliar. Dibanding kebutuhan dana restrukturisasi yang sebesar Rp 44 triliun lebih, dana sebesar itu tentu saja masih jauh dari cukup. Karena itu, keterlibatan lembaga pembiayaan khususnya perbankan sangat diperlukan.

Permasalahan lain adalah maraknya tekstil impor ilegal yang masuk ke pasar domestik terutama dari China. Jumlah tekstil ilegal ini diperkirakan menguasai hampir 50 persen pasar tekstil domestik yang mencapai 1.013 ribu ton pada 2006 . Diperkirakan produk TPT ilegal yang masuk melalui pelabuhan mencapai 74 persen dan melalui bandara 25 persen. Di Bandara Soekarno Hatta Cengkareng, produk TPT ilegal masuk dalam bentuk pakaian jadi.

5 Sumber : http://indonesiatextile.com 
Selain permasalahan di atas, industri TPT mempunyai masalah terkait biaya energi yang mahal, yang merupakan permasalahan lain yang mengganggu daya saing produk tekstil di Indonesia. Pada 2005 misalnya, biaya listrik yang dikeluarkan industri TPT Indonesia mencapai US\$ 0.08 (8 cent/kwh, tertinggi dibanding negara lain yang hanya sebesar 7,6 cent/kwh di China, 7 cent/kwh di Vietnam, 6,6 cent/kwh di Pakistan, dan 3 cent/kwh di Bangladesh dan Mesir. Disamping mahal, kebutuhan listrik juga belum mampu dipenuhi secara optimal oleh PLN.

Sedangkan untuk biaya tenaga kerja, Indonesia merupakan yang tertinggi diantara negara produsen lainnya. Bila negara Bangladesh dan Vietnam hanya membayar upah buruh sebesar US\$ 0,35/ jam, Pakistan US\$ 0,40/jam, India US\$ 0,6/jam, Indonesia membayar lebih mahal yakni lebih dua kalinya Bangladesh dan Vietnam, yakni sebesar US\$ 0,76/jam. Selain itu Indonesia masih harus mengeluarkan biaya pelabuhan yang cukup mahal, termahal kedua diantara negara-negara ASEAN setelah Singapura.

\section{PEMBAHASAN}

\subsection{Kondisi Industri Tekstil dan Produk Tekstil (TPT )}

Sampai dengan akhir tahun 2009, kondisi industri TPT mengalami kenaikan jumlah perusahaan TPT dari 2.818 perusahaan menjadi 2.853 perusahaan atau bertambah 35 perusahaan. Dari jumlah perusahaan tersebut yang bergerak di subsektor pertenunan (weaving) sebesar 37,4 persen dan pakaian jadi (garment) sebesar 34,9 persen. Dua subsektor inilah yang mendominasi industri TPT di Indonesia. Kemudian diikuti subsektor produk tekstil lainnya (others textile product) sebesar 18,8 persen, subsektor pemintalan (spinning) sebesar 7,9 persen dan subsektor produksi serat (fiber) sebesar 1,1 persen. Gambaran tersebut dapat dilihat pada Grafik 3.1, berikut ini.

Grafik 3.1. Jumlah Perusahaan dan Jumlah Share Industri TPT Tahun 2008-2009

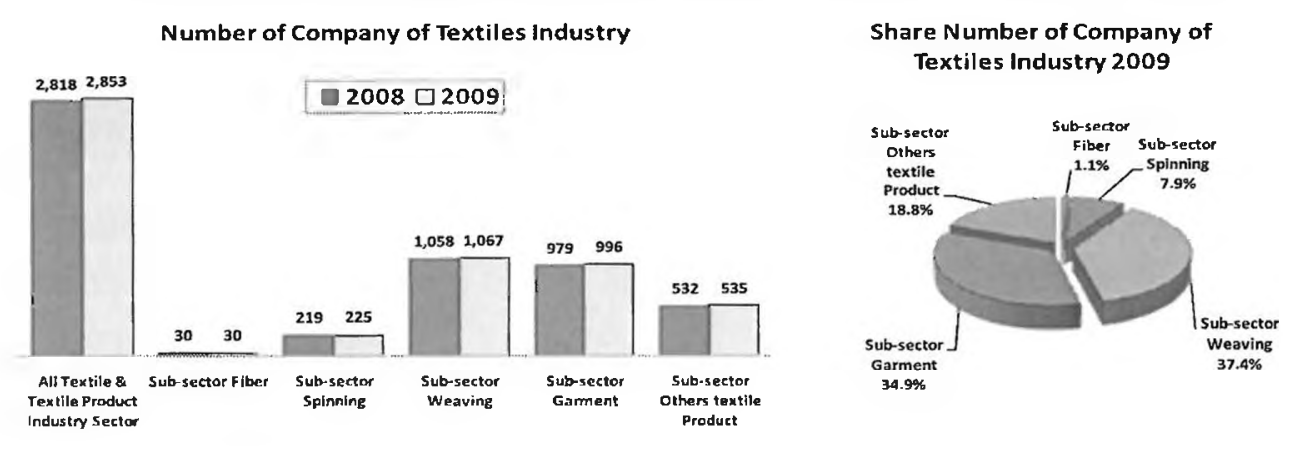

Sumber : Asosiasi Pertekstilan Indonesia, diolah, 2010 
terserap pada kebijakan ini. Namun di sisi lain, sebagian besar pabrik TPT China padat teknologi dan minim tenaga kerja.

\subsection{Peranan Industri TPT Dalam Perekonomian Indonesia}

Peranan industri TPT cukup besar terhadap perekonomian Indonesia, terutama dalam peningkatan nilai ekspor non migas. Data Biro Pusat Statistik, nilai ekspor per Mei 2010 mencapai US $\$ 12,52$ miliar atau mengalami peningkatan sebesar 4,06 persen dibanding ekspor April 2010 dan bila dibandingkan dengan bulan yang sama tahun 2009 mengalami peningkatan sebesar 36 persen. Nilai ekspor non migas Mei 2010 mencapai US $\$ 10,25$ miliar, naik menjadi 4,30 persen dibanding April 2010, sedangkan bila dibandingkan dengan ekspor Mei 2009 meningkat 27,02 persen.

Kinerja ekspor TPT dari tahun 2000 sampai tahun 2009 meningkat 11,59\%, atau rata-rata 3,41\% per tahun, atau setara dengan nilai ekspor USD9,26 miliar. Meski cenderung stagnan, jika dibanding nilai impor, industri tekstil masih menunjukkan surplus. Selama 10 tahun terakhir surplus perdagangan selalu di atas USDS 5 miliar, dan pada tahun 2009 lalu mencapai USD5,09 miliar.

Demikian juga perkembangan jumlah perusahaan terus meningkat dari tahun ke tahun. Data perkembangan perusahaan 2004-2008 rata-rata meningkat sebesar 1,45 persen. Peningkatan jumlah perusahaan dibarengi juga dengan peningkatan investasi rata-rata sebesar 1,74 persen. Dengan masuknya investasi dan penambahan perusahaan industri TPT tersebut dari data 2004-2008, rata-rata terjadi peningkatan penambahan tenaga kerja sebesar 2,17 persen. Ekspor juga meningkat menjadi 7,39 persen. Namun peningkatan impor produk industri TPT lebih tinggi dari produk ekspornya yaitu sebesar 42,99 persen. Apalagi hal ini sebagian besar merupakan impor produk industri TPT dari China baik legal maupun ilegal.

\subsection{Kendala-Kendala Yang Dihadapi Industri TPT}

Dengan diberlakukannya AC-FTA, pada dasarnya industri TPT Indonesia belum sepenuhnya siap menghadapinya. Di sisi lain Indonesia mempunyai struktur industri tekstil yang beragam, namun sampai saat ini masih mempunyai beberapa kelemahan bila dibandingkan dengan industri yang sama di China, kekurangan dan kelemahanya tersebut antara lain :

- Ketersediaan bahan baku kapas hampir sebesar 99 persen masih impor;

- Kondisi permesinan industri TPT 80 persen sudah tua (berusia diatas 20 tahun) mengakibatkan rendahnya produktivitas, dan terjadi pemboros an energi;

- Waktu delivery yang lambat karena beberapa permasalahan administrasi; 
- Indonesia tidak mempunyai industri permesinan tekstil dan dye-stuffs sehingga masih tergantung pada peralatan impor;

- Kondisi energi listrik dan infrastruktur jalan serta pelabuhan yang belum memadai;

- $\quad$ Tingkat suku bunga bank yang masih terlalu tinggi (14-16 persen per tahun). Permasalahan dan kendala-kendala ini menjadikan daya saing industri TPT Indonsia mengalami penurunan dibandingkan dengan industri TPT negara lain terutama dari China.

\subsection{Langkah-langkah kebijakan Pemerintah Terhadap Industri TPT}

Pemerintah telah melakukan beberapa langkah kebijakan mulai dari tahun 2007 untuk meningkatkan kinerja industri TPT melalui serangkaian program sebagaimana Tabel 3.2, yang antara lain sebagai berikut :

Tabel 3.2. Program Peningkatan Kinerja Industri TPT

\begin{tabular}{|c|c|}
\hline $\begin{array}{c}\text { Kelompok } \\
\text { Produk }\end{array}$ & Program \\
\hline Kain & $\begin{array}{l}\text { - Restrukturisasi mesin-mesin pertenunan serta penambahan kapasitas terpasang mesin- } \\
\text { mesin perajutan yang sudah dimulai sejak tahun } 2007 \text { sampai saat ini. } \\
\text { - Modernisasi mesin Dyeing, Printing dan Finishing agar dapat berproduksi dengan } \\
\text { prinsip Small Lot - Small Batch. } \\
\text { - Mendorong industri Finishing menggunakan pewarna organik yang ramah lingkungan. } \\
\text { - Peningkatan kemampuan SDM berkualitas dalam manufakturing dyeing dan finishing. } \\
\text { - Fasilitasi kegiatan promosi melalui penyelenggaraan Pameran-pameran. } \\
\text { - Penerapan Standar Bahan Kimia (Azo dan Formaldehyde) pada Kain Pakaian Bayi. } \\
\text { - Diversifikasi produk dengan produk development pada kain tenun dan kain rajut (fabrics } \\
\text { development) }\end{array}$ \\
\hline Garmen & $\begin{array}{l}\text { - Restrukturisasi Permesinan dan Perluasan Kapasitas Produksi. } \\
\text { - Peningkatan kemampuan industri dalam memenuhi standar teknis dan Social } \\
\text { Compliance, Keamanan dan Keselamatan, dan Lingkungan. } \\
\text { - Kolaborasi antara Produsen dengan Designer untuk dapat menghasilkan garment } \\
\text { fashion. }\end{array}$ \\
\hline
\end{tabular}

Sumber : Bahan Munas XII API 2010, diolah

Menurut Data Kementerian Perindustrian, industri Tekstil dan Produk Tekstil (TPT) Indonesia selama lima tahun terakhir cenderung melambat. Melambatnya industri tekstil ini disebabkan munculnya banyak negara pesaing, seperti India, Vietnam, Bangladesh, Thailand, dan China, yang menggunakan teknologi baru. Di samping itu, juga masih kurangnya optimalisasi utilisasi 
kapasitas terpasang dan terbatasnya kemampuan mesin dalam proses produksi. Sekitar 80 persen mesin-mesin pada industri TPT telah berusia lebih dari 20 tahun. Hal ini mengakibatkan inefisiensi produksi dan terbatasnya kemampuan melakukan diversifikasi produk dan peningkatan kualitas.

Pemerintah (khususnya Kementerian Perindustrian) terus mempertahankan program restrukturisasi permesinan industri TPT sampai dengan tahun 2010 ini dengan nilai anggaran Rpl40 miliar. Bantuan pendanaan restrukturisasi mesin TPT ini dimulai sejak tahun 2007. Selama periode tahun 2007-2009 pemerintah telah menyalurkan bantuan sebesar Rp506,3 miliar yang mendorong investasi pembelian mesin dan peralatan industri TPT senilai Rp4,833 triliun oleh 300 industri TPT nasional.

Selama program tersebut berlangsung sejak tahun 2007, daya saing industri TPT Indonesia mengalami peningkatan, terlihat dari sejumlah indikator. Indikator tersebut, antara lain berupa peningkatan produksi industri TPT Indonesia sebesar 17 - 28persen, penghematan energi sebesar 6 -18 persen, dan peningkatan produktivitas sebesar $7-17$ persen, sehingga proses produksi lebih cepat. Program itu juga dinilai akan mampu menyerap tenaga kerja baru sekitar 42 ribu orang. (Munas API XII, 2010)

Berbeda dengan tahun-tahun sebelumnya, pada tahun 2010 ini pemerintah hanya menerapkan satu skema dalam penyaluran bantuan restrukturisasi permesinan yaitu skema I. Skema I ini berupa pemotongan harga terhadap sejumlah pembelian mesin oleh perusahaan industri TPT. Sementara itu skema II yang memberi bantuan pemberian kredit dengan suku bunga rendah yaitu 7 persen. Kebijakan ini ternyata penyerapannya rendah dan memiliki kendala dalam pengembalian kredit. (Munas API XII, 2010)

Ada 81 perusahaan TPT yang berhasil dalam program restrukturisasi permesinan dengan melakukan peremajaaan mesin dan peralatan di atas Rp10 miliar. Sebagian besar industri TPT itu berasal dari Jabar ( 50 perusahaan) dengan total investasi Rp2,5 triliun dan jumlah bantuan program senilai Rp223,8 miliar. Sisanya, berasal dari Jateng (14 perusahaan) dengan investasi Rp924 miliar dan jumlah bantuan program sebesar Rp70,9 miliar. Banten (10 perusahaan) dengan investasi Rp483,5 miliar dan jumlah bantuan Rp36,I miliar, Jatim (5 perusahaan) dengan total investasi Rp163,4 miliar dengan jumlah bantuan Rp15,7 miliar, dan DKI Jakarta (10 perusahaan) dengan investasi Rp32 miliar dengan jumlah bantuan Rp3,l miliar.

Asosiasi Pertekstilan Indonesia (API) sebagai organisasi pertekstilan di Indonesia berharap agar program restrukturisasi permesinan TPT harus terus dilanjutkan guna meningkatkan daya saing karena teknologi mesin pertekstilan relatif cepat berubah, hampir setiap lima tahun sekali. Demikian juga keberadaan industri TPT harus dipertahankan karena menyerap tenaga kerja yang besar yaitu 
sekitar 15 persen, atau sebanyak 1.841 .520 orang. Industri ini juga mampu memberi surplus perdagangan sebesar 24,33 persen pada tahun 2007. Bahkan di tengah krisis keuangan dunia tahun 2008, industri TPT nasional masih mampu meraih surplus sebesar USD8 miliar. ${ }^{6}$

Menurut para pelaku usaha industri TPT terkait ekspansi usaha ini masih ada beberapa kendala di tengah persaingan ketat pasca-perjanjian perdagangan bebas Asean dan China (ACFTA). Pertama, terbatasnya sumber daya manusia yang mempunyai keahlian teknik menangani pertekstilan. Kedua, terkait masalah upah buruh. Pekerja selalu menuntut kenaikan upah sementara pengusaha dengan alasan efisiensi jelas menolak tuntutan tersebut. Sementara itu tahun 2011, Pemda akan memberlakukan kenaikan upah 5\%. Hal ini tentu memberatkan pelaku usaha. Ketiga, masalah pembiayaan. Saat ini perbankan masih menilai industri TPT sebagai sunset industry, yaitu usaha yang sudah tidak menarik lagi. Padahal, kinerja industri TPT terus meningkat, sehingga semestinya perlu diberikan pembiayaan yang cukup dan tidak lagi dikategorikan sebagai industri yang berprospek kurang cerah. ${ }^{7}$

Keempat, banyaknya bahan baku yang masih harus diimpor, seperti kapas, serat sintetis, maupun bahan baku lainnya termasuk bahan penolong. Problem bahan baku ini menunjukkan bahwa peningkatan kinerja industri TPT bukan hanya menyangkut para pelaku usaha semata, namun pemerintah sudah selayaknya ikut serta mendorong pasokan bahan baku, antara lain melalui budi daya kapas. Pemerintah dapat mendorong dengan memberikan bantuan kredit murah untuk pengadaan bahan baku. Kelima, permasalahan energi, terutama pasokan listrik yang terbatas. Maka pemerintah sepenuhnya mendorong pemenuhan kebutuhan energi dengan program penyediaan energi listrik 10,000 Megawatt tahap kedua. Keenam, restrukturisasi mesin yang masih harus dioptimalkan. Ketujuh, fasilitas pelabuhan yang tidak memadai. Terkait dengan pasokan energi, dalam hal ini listrik, kenaikan Tarif Dasar Listrik (TDL) diperkirakan akan mengganggu kinerja Industri TPT. Apabila pemerintah tidak dapat memenuhi kebutuhan energi industri TPT, maka ke depan tampaknya akan menjadi hambatan bagi industri TPT di Tanah Air. Demikian juga dengan pembatasan alokasi gas dan listrik ini menyebabkan iklim usaha semakin tidak kondusif.

Keterbatasan listrik ini juga berpengaruh terhadap realisasi investasi baru di sektor spinning (pemintalan) dan mengancam terhentinya pabrik-pabrik TPT yang sudah eksis. Saat ini industri TPT berencana meningkatkan investasi hingga USD200 juta, terutama di subsektor pemintalan seiring dengan upaya peremajaan

6 Ansari Bukhari, 2010.

7 Ade Sudrajat Usman, Performance of Indonesian Textiles Industry, 2010 
mesin-mesin TPT yang sudah tua. Akibatnya, permintaan benang ke depan akan meningkat sehingga dibutuhkan modal baru untuk meremajakan mesin-mesin produksi dan menambah kapasitas.

Di sisi lain, setelah perdagangan bebas dengan China, Indonesia juga akan menghadapi pasar bebas dengan India. Perjanjian perdagangan bebas itu sudah ditandatangani dalam KTT Pemimpin ASEAN tahun 2009. Walaupun ancaman perdagangan bebas ASEAN dengan India atau AIFTA (ASEAN-India Free Trade Area) tidak sebesar ACFTA. Produk Indonesia memiliki peluang masuk ke pasar TPT di India. Namun komoditas tekstil seperti polyester, serat, dan benang katun dari India akan banyak memasuki pasaran di Indonesia setelah AIFTA berlaku, karena India merupakan penghasil besar produk-produk tersebut.

\subsection{Penguatan Daya Saing Industri TPT Nasional}

Gencarnya persaingan dunia industri TPT sudah selayaknya diambil langkah -langkah antisipatif. Langkah-langkah prioritas untuk segera dilaksanakan Pemerintah dalam rangka peningkatan daya saing antara lain penguatan daya saing industri TPT nasional, yang meliputi kebijakan antara lain di bidang :

a) Pembenahan infrastruktur dan energi;

b) Pemberian insentif (pajak maupun non pajak lainnya) termasuk kredit perbankan;

c) Membangun Kawasan Ekonomi Khusus (KEK);

d) Penyederhanaan peraturan; dan

e) Peningkatan kapasitas ketenagakerjaan.

Langkah-langkah prioritas lainnya untuk penguatan daya saing industri TPT nasional adalah pengamanan pasar domestik, yang meliputi :

a) Penerapan Early Warning System (EWS) untuk pemantauan dini terhadap kemungkinan terjadinya lonjakan impor.

b) Pengawasan awal terhadap kepatuhan SNI (Standar Nasional Indonesia), Label, Ingridien, kadaluarsa, kesehatan, lingkungan, security dan sebagainya.

c) Penerapan instrumen perdagangan yang diperbolehkan WTO (safeguard measures)terhadap industri yang mengalami kerugian yang serius (seriously injury) akibat tekanan impor (import surges).

d) Penerapan instrumen anti dumping dan countervailing duties atas importasi yang un-fair.

Sebagai perbandingan, di bawah ini adalah beberapa faktor yang mempengaruhi daya saing produk industri TPT Indonesia dibandingkan dengan produk TPT China dan langkah-langkah pemerintah yang perlu dilakukan untuk meningkatkan daya saing, seperti pada Tabel 3.3, sebagai berikut : 
Tabel 3.3. Faktor-Faktor Yang Mempengaruhi Daya Saing Industri TPT Indonesia dengan China

\begin{tabular}{|c|c|c|c|c|}
\hline No & Faktor & Indonesia & China & $\begin{array}{c}\text { Hal-hal yang periu } \\
\text { dilakukan }\end{array}$ \\
\hline 1 & $\begin{array}{l}\text { Kondisi } \\
\text { Permesinan } \\
\text { Industri TPT }\end{array}$ & $\begin{array}{l}>20 \text { tahun dan baru } 6 \% \\
\text { dilakukan program } \\
\text { restrukturisasi mesin dari } \\
\text { pemerintah sejak tahun } 2007\end{array}$ & $\begin{array}{l}<10 \text { tahun dan telah } \\
\text { melakukan peremajaan } \\
\text { mesin sejak tahun } 2000\end{array}$ & $\begin{array}{l}\text { Program Restrukturisasi } \\
\text { mesin industri TPT terus } \\
\text { dilanjutkan }\end{array}$ \\
\hline 2 & $\begin{array}{l}\text { Dukungan } \\
\text { Perbankan }\end{array}$ & Suku bunga $14 \%$ & Suku bunga $6 \%$ & $\begin{array}{l}\text { Agar Bank Indonesia } \\
\text { mendorong perbankan } \\
\text { nasional } \\
\text { menurunkan } \quad \text { suku } \\
\text { bunga komersial } \\
\text { dibawah } 1 \text { digit }\end{array}$ \\
\hline \multirow{6}{*}{3} & Energi Listrik & & & \\
\hline & - Tarif & USD 0,08/kWh & USD $0,09 / \mathrm{kWh}$ & $\begin{array}{l}\text { Agar PLN menerapkan } \\
\text { salu tarif yang seragam } \\
\text { untuk industri }\end{array}$ \\
\hline & $\begin{array}{l}\text {-Supply (Jam } \\
\text { beroperasi) }\end{array}$ & $\begin{array}{l}\text { Tidak kontinyu sehingga ada } \\
\text { penambahan biaya (tidak } \\
\text { ekonomis untuk perusahaan) }\end{array}$ & stabil & $\begin{array}{l}\text { Dicabutnya SKB } 5 \\
\text { Menteri tentang } \\
\text { pengalihan hari kerja ke } \\
\text { hari sabtu dan minggu }\end{array}$ \\
\hline & $\begin{array}{l}\text {-Waktu Beban } \\
\text { Puncak }\end{array}$ & Daya max $=R p 1300 / \mathrm{kWh}$ & USD 0,09/kWh & $\begin{array}{lr}\text { Pemakaian pada jam } \\
00.00-06.00 \quad \text { WIB } \\
\text { industri diberi } \\
\text { keringanan atau intensif }\end{array}$ \\
\hline & $\begin{array}{l}\text {-Sambungan } \\
\text { Baru }\end{array}$ & Multiguna $=\mathrm{Rp} 1300 / \mathrm{kWh}$ & USD $0,09 / \mathrm{kWh}$ & \\
\hline & $\begin{array}{l}\text { Kesesuaian } \\
\text { Daya }\end{array}$ & $\begin{array}{l}\text { Beban yang dipasang oleh } \\
\text { industri melebihi kapasitas } \\
\text { pemakaian maksimum } \\
\text { produksi }\end{array}$ & $\begin{array}{l}\text { Beban yang dipasang } \\
\text { sesuai dengan kebutuhan }\end{array}$ & $\begin{array}{l}\text { Mendorong industri } \\
\text { untuk menyesuaikan } \\
\text { pemakaian daya listrik }\end{array}$ \\
\hline \multirow{3}{*}{4} & PPN & & & \\
\hline & -Restitusi & $\begin{array}{l}10 \% \text { namun tidak ada } \\
\text { kepastian waktu }\end{array}$ & $17 \%$ dengan waktu 25 hari & $\begin{array}{l}\text { Restitusi di percepat } \\
\text { menjadi } 30\end{array}$ \\
\hline & -Faktur Pajak & $\begin{array}{l}\text { Kewajiban penggunaan faktur } \\
\text { pajak standar }\end{array}$ & & $\begin{array}{l}\text { Penyederhanaan } \\
\text { dokumentasi }\end{array}$ \\
\hline
\end{tabular}

Sumber : Kementerian Perindustrian, diolah, 2010 


\subsection{Struktur Biaya Industri Tekstil dan Produk Tekstil Indonesia}

Perkembangan industri TPT saat ini baik industri serat, benang, tekstil maupun garmen tidak sepesat perkembangannya saat dekade 1990-an. Hal ini mengingat banyaknya masalah yang terjadi baik dalam segi finansial, manajemen perusahaan atau kondisi pemasaran yang semakin menurun, persaingan semakin banyak maupun kondisi investasi yang tidak kondusif. Dari sisi finansial sendiri, beban biaya TPT semakin meningkat terutama biaya bahan baku dan bahan penolong, biaya energi maupun biaya tenaga kerja. Sebagaimana dapat dilihat pada Tabel 3.4. berikut ini :

Tabel 3.4.Struktur Biaya Tekstil dan Produk Tekstil (\%)

\begin{tabular}{|c|c|c|c|c|c|}
\hline No & Biaya & Serat & Benang & Tekstil & Garmen \\
\hline 1 & $\begin{array}{l}\text { Bahan Baku \& Bahan } \\
\text { Penolong }\end{array}$ & 53,00 & 58,13 & 56,48 & $57,65-66,73$ \\
\hline 2 & Tenaga Kerja & 6,00 & 6,39 & 13,31 & $18,00-27,08$ \\
\hline 3 & Energi & 25,00 & 18,47 & 14,37 & 1,33 \\
\hline 4 & Penyusutan & 6,00 & 5,94 & 2,1 & 1,36 \\
\hline 5 & Bunga (Cost of Money) & 4,00 & 6,09 & 6,35 & 2,4 \\
\hline 6 & Administrasi \& Marketing & 3,00 & 4,98 & 7,39 & 10,18 \\
\hline 7 & Lain-lain & 3,00 & 0 & 0 & 0 \\
\hline & Total & 100 & 100 & 100 & 100 \\
\hline
\end{tabular}

Sumber : Kementerian Perindustrian, 2010

Dari tabel di atas terlihat bahwa biaya bahan baku merupakan komponen biaya yang paling dominan dalam struktur biaya industri TPT. Ini menunjukkan harga pokok produksi industri TPT sangat dipengaruhi bahan dasar dan bahan penolong yang lebih dari 50 persen. Tentu saja bila bahan dasar dan bahan penolongnya merupakan komponen impor maka akan meningkatkan harga pokok produksi industri TPT.

Komponen biaya yang penting ke dua dalam industri TPT adalah biaya tenaga kerja. Rata-rata biaya tenaga kerja, hampir 10 persen. Untuk produksi garmen, tenaga kerja lebih banyak menyerap tenaga kerja sehingga diperlukan tenaga-tenaga kerja yang lebih spesifik. Menyusul tenaga kerja untuk industri produk tekstil, benang dan serat. Komponen tenaga kerja ini akan menjadi hambatan karena sistem dan peraturan ketenagakerjaan di Indonesia sering mengalami perubahan.

Komponen biaya industri TPT yang sangat penting lainnya adalah biaya administrasi dan marketing khususnya industri garmen yang lebih dari 10 persen 
total biaya produksinya. Menyusul industri tekstil dan benang serta serat. Biaya administrasi dan marketing Industri garmen tinggi dikarenakan persaingan industri ini cukup ketat baik pasaran dalam negeri maupun produk ekspor. Demikian juga untuk produk tekstil. Produk tekstil adalah salah satu produk andalan Indonesia. Produk ini banyak menyerap tenaga kerja, hampir 15 persen dari tenaga kerja disektor manufaktur atau sebesar 1,841 juta pekerja pada tahun 2004 dan kemudian berturut-turut tahun 2005 sebesar 1,176 juta orang, tahun 2006 sebesar 1,191 juta orang, tahun 2007 sebesar 1,234 juta orang dan tahun 2008 sebesar 1,289 orang. Selain itu industri ini dapat menyumbang hampir 24,33 persen surplus perdagangan Indonesia. 8

\section{KESIMPULAN DAN SARAN}

\subsection{Kesimpulan}

Kinerja industri TPT Indonesia sebagai industri strategis yang banyak menyerap tenaga kerja dan pencipta devisa serta penyedia kebutuhan sandang dalam negeri lima tahun terakhir mengalami perlambatan. Sampai dengan akhir tahun 2009 pertumbuhan rata-ratanya hanya sebesar 3,41 persen pertahun. Pertumbuhan yang relatif stagnan tersebut adalah sebagai akibat dampak krisis ekonomi global maupun semakin banyaknya industri TPT dari berbagai negara terutama China yang menggunakan teknologi baru. Sementara melemahnya industri TPT Indonesia juga dipengaruhi kurang optimalnya utilisasi kapasitas terpasang, serta hampir 80 persen mesin-mesin yang digunakan adalah sudah lebih dari 20 tahun yang mengakibatkan inefisiensi.

Komponen biaya yang paling tinggi pada industri TPT Indonesia adalah bahan baku dan bahan penolong yang lebih dari 50 persen dari total biaya. Bahan baku dan bahan penolong tersebut sebagian besar masih diimpor, seperti ketersediaan bahan baku kapas, 99 persen diantaranya masih impor. Oleh karenanya membutuhkan biaya bahan baku cukup besar yang kemudian menyebabkan harga produk industri TPT Indonesia menjadi lebih mahal dan kurang dapat bersaing.

Peranan pemerintah belum sepenuhnya mendukung industri TPT, terutama dalam sektor keuangan seperti pemberian kredit lunak guna peremajaan permesinan yang belum optimal serta kurangnya ketersediaan bahan baku dalam negeri untuk industri TPT.

\footnotetext{
8 Data dari Menperin tahun 2009 http://bisnis.vivanews.com/news/read/106668menperin mimpi indonesia jadi raksasa tekstil
} 


\subsection{Saran}

Untuk meningkatkan kinerja industri TPT Indonesia yang mengalami perlambatan lima tahun terakhir semestinya pemerintah terus meningkatkan dukungannya melalui berbagai skim, diantaranya penyediaan kredit untuk modal kerja dan investasi guna mendukung alih teknologi dan peremajaan mesin-mesin lama maupun pembiayaan proyek infrastruktur guna mendukung aktivitas ekspor. Demikian juga penyediaan dan memfasilitasi penyediaan sumber energi/listrik PLN yang memadai.

Dalam rangka meningkatkan daya saing produk industri TPT Indonesia, pemerintah dapat mendukungnya melalui kebijakan penyederhanaan fasilitas pabean dan perpajakan agar hasil produk industri TPT Indonesia dapat bersaing dengan produk negara lain. Demikian juga perbaikan tata niaga impor khususnya menangkal produk TPT ilegal dari beberapa negara terutama China, termasuk meningkatkan produktivitas dan efisiensi kinerja pelabuhan untuk mengurangi kemacetan arus barang.

Komponen harga pokok ITPT yang paling besar adalah berasal dari biaya bahan baku dan bahan penolong. Untuk ITPT Indonesia, hampir 50 persen komponen bahan baku dan bahan penolongnya tersebut berasal dari impor. Oleh karena itu untuk menurunkan biaya harga pokok yang tinggi, diupayakan pemenuhan kebutuhan bahan baku dalam negeri guna mencukupi kebutuhan bahan baku ITPT seperti perluasan perkebunan kapas, maupun terus dilakukannya penambahan dan perbaikan industri hulu TPT dalam negeri.

\section{Daftar Pustaka}

-, Sambutan Menteri Perindustrian pada Acara Musyawarah Nasional XII API bertajuk Kawasan Perdagangan Bebas Asean: "Peluang dan Tantangan" serta Pameran Bandung Intertex 2010

Ade, Sudrajat, Usman, Kinerja industri TPT Indonesia dan Integrasi Industri dan Perdagangan TPT Asean (Performance of Indonesian textiles Industry), API, Bahan Seminar tanggal 24 April 2010, Kemayoran Jakarta

Bukhari, Ansari, (2010), "Dukungan Pemerintah Dalam Peningkatan Daya Saing Industri TPT Indonesia Menghadapi Integrasi Tekstil Asean",

Gurley, R.J, Asean Competitiveness Enhancement (ACE) Project, Bandung Intertex 2010 
Kuncoro, Haryo., (2002), "Upah Sistem Bagi Hasil dan Penyerapan Tenaga ", Jurnal Ekonomi Pembangunan hal 45-56 Vol 7 no.1 tahun 2002

Kuncoro, Mudrajat, Ekonomika Industri Indonesia Menuju Negara Industri baru 2030, Penerbit Andi Yogyakarta, 2007

Kotler, Philip and Kevin Lane Keller, 2006. Metodologi Penelititan: Aplikasi dalam Pemasaran, Jakarta: PT Gramedia. Utami, C. Whidya, 2006.

Subiyanto, Heru dan Riphat, Singgih, Kebijakan, Fiskal, Pemikiran Konsep dan Implementasi, Penerbit Buku Kompas, 2004

Tambunan, Tulus, Perdagangan Internasional dan Neraca Pembayaran, Teori dan temuan Empiris, LP3ES, Jakarta, 2000

http://bataviase.co.id/node/202572

http://bantenindustrialcluster.com/index.php?option=com content\&view=article \&id=1222:produksi-tpt-anilok-374-api-penurunan-ekspor-capai-titikterendah\&catid $=43$ :perdagangan\&Itemid $=58$

http://www.koran-iakarta.com/berita-detail.php?id=38342

http: / /indonesiatextile.com/index.php?option=com content\&task=view\&id=21\&It emid $=1$

http://buruhindependent.blogspot.com/2009/06/industri-tekstil-dan-produktekstil-tpt.html? 


\section{Lampiran 1}

\section{Urutan Negara Suplier Garmen Ke Amerika}

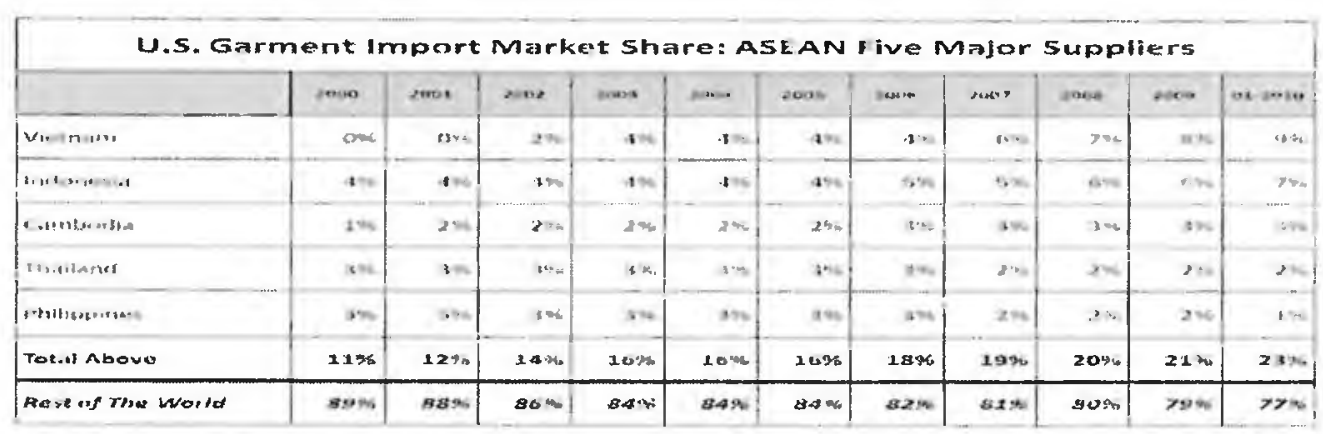

Sumber : Asean Federation of Textile industries (Aftexis)-Asean Fuel Service Alliance (Safsa), 2010

\section{Lampiran 2}

Lima Negara Asean Suplier Garmen ke Amerika

\begin{tabular}{|c|c|c|c|c|c|c|c|c|c|c|c|}
\hline \multicolumn{12}{|c|}{ U.S. Garment Import Suppliers by Rank } \\
\hline & 2000 & 2001 & 2002 & 2003 & 2002 & 2005 & 2000 & 2007 & $2 \operatorname{ccs} 3$ & 2009 & $01-2010$ \\
\hline Greater China & 1 & 1) & 1 & 1 & 1 & 1 & 1 & 1 & 1 & 1 & 1 \\
\hline Vietnam & 58 & 60 & 20 & 3 & 4 & 5 & 4 & 3 & 2 & 2 & 2 \\
\hline Indonesia & 8 & 5 & 6 & 5 & 5 & 4 & 3 & 4 & 3 & 3 & 3 \\
\hline Bangladesty & 6 & 7 & 8 & 9 & of & 7 & 6 & 6 & s) & 4 & (i) \\
\hline India & 11 & 11 & i) & 7 & 6 & 3 & 5 & 3 & 0 & 8 & 5 \\
\hline Mexico & 2 & 2 & 27 & 2 & $?$ & $?$ & 2 & 2 & $\therefore$ & 5 & . \\
\hline Cambodia & 21 & 19 & 29 & 201 & 18 & 12 & 9 & 8 & 8 & 8 & 7 \\
\hline Horduras & $\therefore$ & 3 & i & 31 & $3 \mid$ & 6 & 7 & 7 & $i$ & $\because$ & 3 \\
\hline S: Lankd & 15 & 13 & 15 & 10 & $i$ & 14 & 12 & 12 & 12 & 21 & 9 \\
\hline Thailand & 10 & 9 & 10 & 13 & 11 & It & 11 & 10 & 9 & 11 & 10 \\
\hline Pdkistan & 121 & 20 & 21 & 21 & 22 & 18 & T', & .3 & 11 & 9 & 11 \\
\hline El Salvador & 13 & 12 & i! & 12 & 13 & 13 & 16 & $\therefore 4$ & 107 & 10 . & 12 \\
\hline Guatemaha & 14 & 13 & 12 & 11 & 9 & 10 & 13 & 15 & 21 & 13 & 13 \\
\hline Philippines & 9 & 8 & 9 & 8 & 12 & 9 & 20 & 11 & 14 & 14 & 11 \\
\hline fawan & $\pi$ & 10 & 1:- & 14 & 15 & 20 & 20 & 21 & 22 & 221 & 20 \\
\hline Malaysia & 22 & 21 & 23 & 22 & 24 & 27 & 26 & 25 & 24 & 23 & 21 \\
\hline Domnean Rep. & 3 & 4 & $:$ & 6 & 7) & 8 & 131 & 17 & is & 181 & 23 \\
\hline Korea & 3 & 6 & 5 & 10 & io & 19 & $\therefore 1$ & 23 & 25 & $\therefore$ & $\Delta$ \\
\hline Singapoie & 27 & 30 & 32 & 33 & $\overline{37}$ & 42 & 37 & 36 & 36 & 47 & 47 \\
\hline
\end{tabular}

Sumber : Asean Federation of Textile industries (Aftexis)-Asean Fuel Service Alliance (Safsa), 2010 